\title{
Employment conditions and health inequities: a case study of Brazil
}

\author{
Condições de emprego e iniquidades em saúde: \\ um estudo de caso no Brasil
}

1 Faculdade de Medicina, Universidade Federal de Minas Gerais, Belo Horizonte, Brasil.

2 Instituto de Saúde Coletiva, Universidade Federal da Bahia, Salvador, Brasil. 3 Escola Nacional de Saúde Pública Sergio Arouca, Fundação Oswaldo Cruz, Rio de Janeiro, Brasil. 4 Área Técnica de Saúde do Trabalhador, Ministério da Saúde, Brasília, Brasil.

Correspondence E. C. Dias Departamento de Medicina Preventiva e Social, Faculdade de Medicina, Universidade Federal de Minas Gerais. Av. Alfredo Balena 190, sala 817, Belo Horizonte, $M G$ 30130-100, Brasil. bethdias@medicina.ufmg.br

\author{
Elizabeth Costa Dias 1 \\ Roberval Passos de Oliveira ${ }^{2}$ \\ Jorge H. Machado 3 \\ Carlos Minayo-Gomez 3 \\ Marco Antonio Gomes Perez 4 \\ Maria da Graça L. Hoefel 4 \\ Vilma Sousa Santana 2
}

\section{Introduction}

This paper was prepared for the Employment Conditions and Health Inequalities Knowledge Network (EMCONET), part of the WHO Commission on the Social Determinants of Health. We describe the Brazilian context of employment conditions, labor conditions and health, their characteristics and causal relationships. The social, political and economic factors that influence these relationships are also presented with an emphasis on social inequalities, and how they are reproduced within the labor market and thereby affect the health and wellbeing of workers. A literature review was conducted in SciELO, LILACS, Google and Google Scholar, MEDLINE and the CAPES Brazilian thesis database. We observed that there are more workers operating in the informal sector than in the formal sector and these former have no social insurance or any other social benefits. Work conditions and health are poor in both informal and formal enterprises since health and safety labor norms are not effective. The involvement of social movements and labor unions in the elaboration and management of workers' health polices and programs with universal coverage, is a promising initiative that is underway nationwide.

Occupational Health; Working Conditions; Job Market; Health Inequalities
Work is a central element of an individual's life and is the main reference for determining patterns of identity and sociability, political activities, family life, access to economic resources and opportunities for achieving good health and wellbeing 1,2 .

Technological and management changes are reshaping labor patterns in Brazil as the economy had changed from being based on mining and agriculture to an industrialized economy focused on manufacturing and services. These changes have had social and economic consequences that are evident in the steady growth of the informal economy and informal employment, low wages, job insecurity, and social inequities. This model of development has been coupled with poor working conditions and increasing damage to the environment. Poverty and work-related illnesses and diseases are the main "byproducts" of these changes, and have themselves further contributed to social inequities.

The aim of this paper is to provide an overview of the Brazilian context, taking into consideration employment regulations and labor-capital relations in the labor market, work conditions and their impacts on health, and how changes in employment conditions and the erosion of social welfare are reshaping social inequalities in health and particularly in workers' health. 


\section{Brazil: historical, geographical and demographic characteristics}

Brazil is the fifth largest country in the world and is one of the most diverse geographic, social and cultural areas of the planet. The official history of Brazil starts in the year 1500, when Portuguese navigators began the occupation of a large part of the American continent, seeking to explore its natural resources and dominate its native indigenous tribes. After the colonial period and a short time as an independent kingdom from Portugal, Brazil became a federative republic in 1889, under the government of a directly elected president. Politically, it is made up of 26 states and the Federal District of Brasilia, which is the seat of the government, and these are further divided into a total of 5,564 municipalities distributed across five geographical regions: the north and northeast; central-west; and south and southeast.

The population was estimated to be $188,244,040$ in 2006 and is unevenly distributed across an area of 8.5 million $\mathrm{km}^{2}$. The Brazilian population is the result of intense miscegenation between the Portuguese and other groups of European and Asia origin, native indigenous tribes and Africans who, during the colonial period, were traded as slaves. The majority of the population, (82\%), lives in urban areas, a consequence of both the economic development model that is focused on the manufacturing and service industries, and of a steady but intensive flow of migrants from the countryside to urban centers during the 1950s. The demographic profile of the country is marked by a decline in mortality and fertility. Between 1940 and 1970, long-term average population growth was $2.8 \%$ per year, but from the year 2000 it began to decline gradually and reached $1.36 \%$ in 2003 . Mortality decreased by $50 \%$ over the previous century and life expectancy at birth doubled over the same period. In 1900 , the estimated life expectancy was 34 , while in 2000, it was 694 . The proportion of individuals aged 60 or more has increased constantly throughout the last century from $3 \%$ in 1900 , to $9 \%$ in 20005

\section{Scenarios: work, employment relations and health conditions}

Brazil has a persistent problem of unequal income distribution that is one of the highest in the world. In 2002, the highest income quintile of the population earned $62.7 \%$ of the country's total income, while the lowest quintile received only $3.4 \%$. In spite of being the $11^{\text {th }}$ ranked economy in the world, with an estimated income per capita of US $\$ 4,700$ in 2005 , Brazil still stands as the $10^{\text {th }}$ most unequal economy in the world. The Human Development Index (HDI), a composite indicator based on longevity, income and education, has increased from 1975 to 2004, and places the country among mid-ranking nations. In recent years, the Gini Index fell from 0.573 in 2002 to 0.559 in 2005 due to a real increase in the minimum wage and an expansion of social security protection based on cash transfer programs 7 .

Economic production in Brazil is characterized by contrasting realities. High-tech and sophisticated management models are used alongside obsolete, handmade production based on rudimentary labor and business organization. Today, the largest component of the Brazilian economy is represented by services $(60 \%)$, while industry and the primary sector both account for around $20 \% 8$, 9 .

Brazil's economically active population (EAP) was estimated to be 96 million in 2005 10. Agricultural workers comprise $20.6 \%$ of the active worker population, and $60 \%$ work in "traditional farming". Approximately one million workers are in the mining trade, $13.5 \%$ in manufacturing, $14.3 \%$ in commerce/retail, $20.2 \%$ in services, and $18.4 \%$ are involved in other services 11 .

During the 1990s a restructuring of the economy and globalization of the market resulted in great changes to the organization of labor, affecting both the meaning and the reality of labor, job stability, wages and consequently workers' health. Issues such as health conditions, social insurance and protection became marginal concerns for Brazilian labor unions compared with other priorities for survival in this era of huge uncertainties. The rolling back of the State and a reduction in its participation in social policies including social compensation, public health, social assistance and occupational health insurance meant that it was difficult to recognize certain rights as laid out in the Brazilian constitution and based on a system of Social Welfare 12 .

\section{Main characteristics of the labor market}

The Brazilian labor market is presently characterized by increasing informality in job contracts and the expansion of many forms of precarious and atypical jobs: outsourcing, temporary or part-time jobs, piece-work and family-based work, as demonstrated in Figure 1.

The growth of the informal economy is associated with an expansion of the services sector and a retraction of manufacturing industries. Informal jobs are also increasing within the manufacturing industry itself, rising from 15\% in 1991 to over $30 \%$ in 2002 . Informal workers frequently 


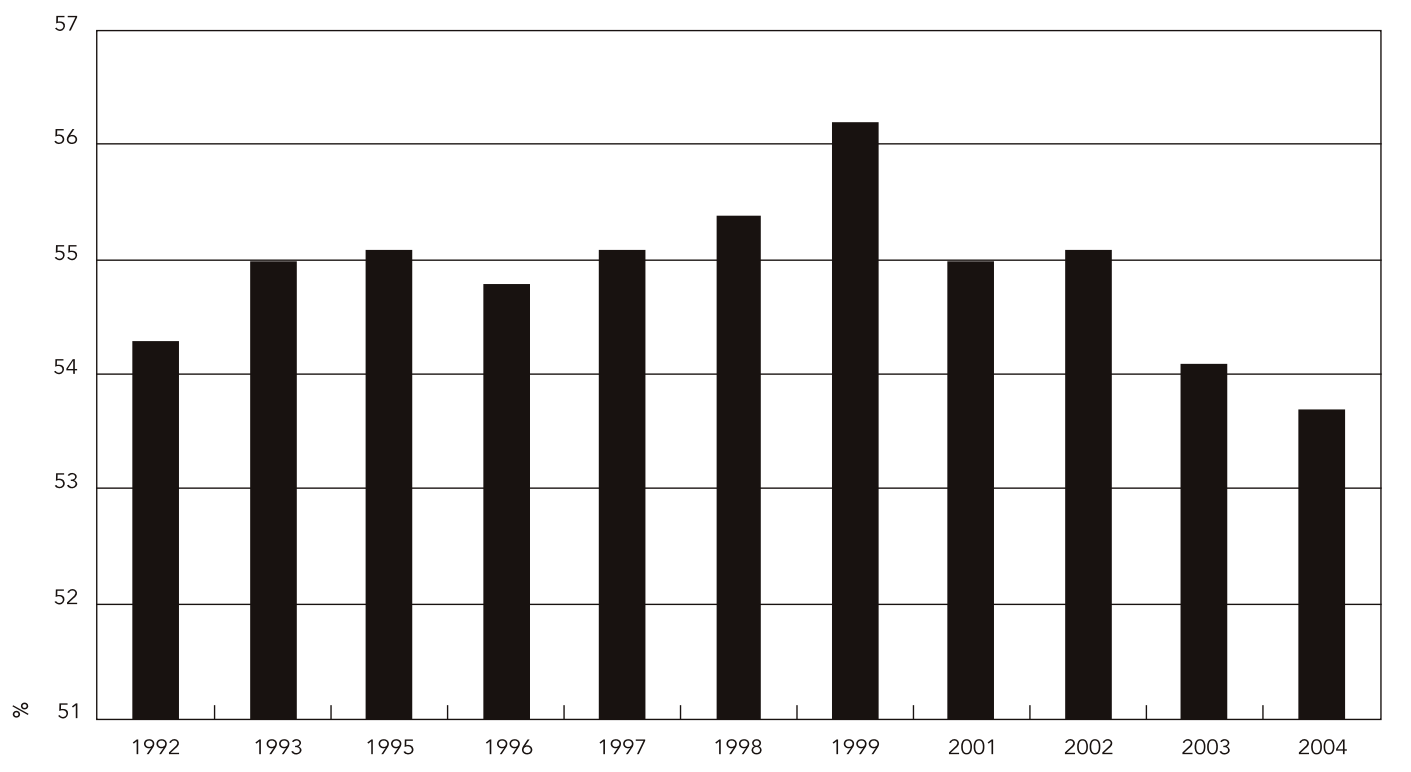

Source: Instituto Brasileiro de Geografia e Estatística 10.

* Definition of informality: (workers without formal contracts + self-employed workers)/(protected workers + workers without formal contracts + self-employed workers).

have little education, reduced professional skills, or are part of vulnerable groups or minorities such as blacks, the young, the elderly and women $13,14,15$. In the lowest $40 \%$ of the income distribution, $31.7 \%$ hold informal jobs, while in the highest $10 \%$, only $8 \%$ of workers have informal jobs 4 .

Poverty and low wages are associated with informal jobs. Figure 2 shows that in the lower income group ( $40 \%$ of the income distribution) the proportion of informal jobs is $31.7 \%$ while in the highest $10 \%$ percentile, only $8 \%$ of workers have informal job contracts. In addition, those in the top ranking income group have an average income of $\mathrm{R} \$ 2,744.30$ (Brazilian Reais) and the poorest $\mathrm{R} \$ 149.854$. Self-employed people make up the highest proportion of workers with per capita average family income of less than half the minimum wage, over $32.1 \%$, 28.6\% and $25.8 \%$, respectively. These categories present the lowest average incomes among the active population: $\mathrm{R}$ \$ 272.60, R\$ 355.10 and $\mathrm{R} \$ 505.00$, respectively, where the minimum wage reference is $R \$ 350.00$. These data show that informal workers, in addition to having no access to legal occupational and social security benefits, earn less than those working in the formal sector 4 .
Women are more affected by unemployment than men. In 2005, women accounted for almost $56 \%$ of the total unemployed population, with an unemployment rate of $13.6 \%$, almost twice the $7.7 \%$ among men. Women also increased their presence in the EAP 16.

One of the most striking aspects of the deterioration of work conditions is the persistent exploitation of child and adolescent labor, both in rural and urban areas. According to the Brazilian National Household Sample Survey (PNAD), 5.5 million children aged between 5 and 17 are in some form of paid employment. Most of these children $(43.7 \%)$ are involved in the agricultural sector ${ }^{4}$. Child labor is also common in informal street markets and in the worst kinds of labor markets involving commercial sexual exploitation, illegal drug selling trafficking 17 .

Slavery is another unacceptable working condition that persists in Brazil, particularly in the agricultural and extractive industries. 25,000 workers are estimated to be living under slavelike conditions in Brazil 18. These workers are lured by job offers in distant places, where they are transported to work under unsafe and unhealthy conditions usually with no regular pay- 


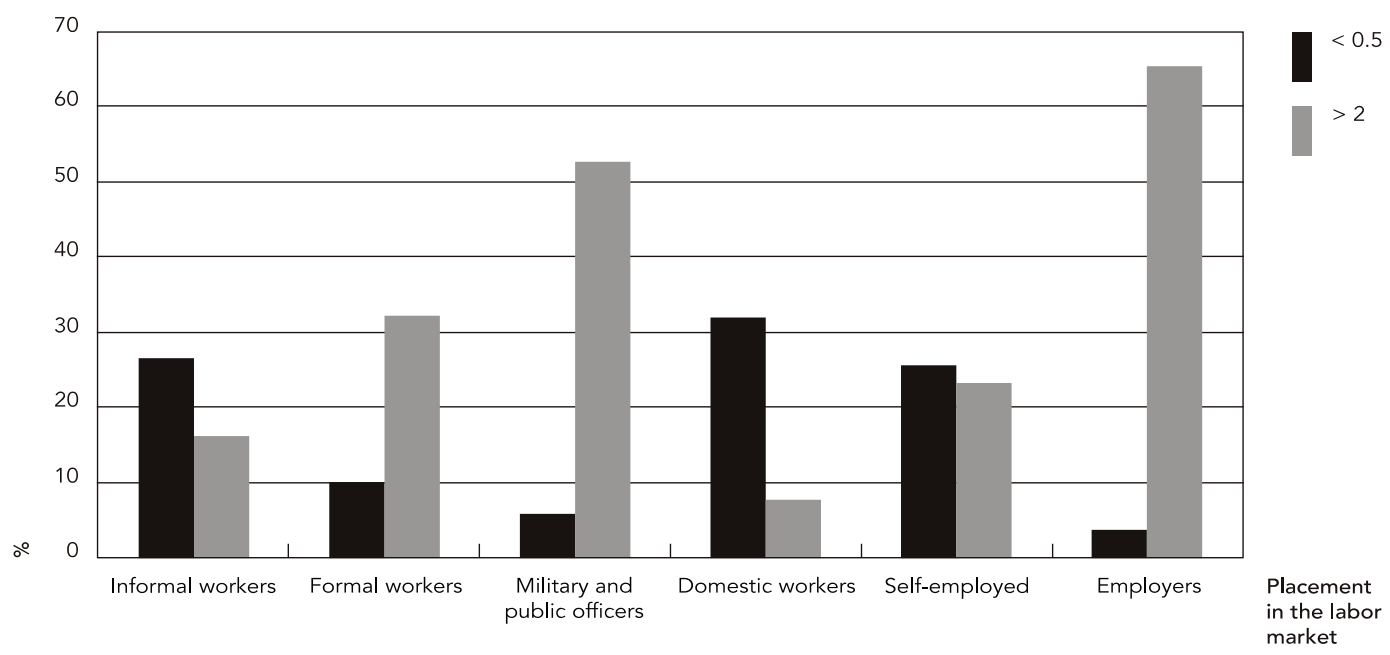

Source: Instituto Brasileiro de Geografia e Estatística 10.

ment and with restrictions placed on their freedoms. Their debts grow and they are unable to free themselves without outside help.

The agro-business has been growing fast over the last three decades, representing a large proportion of GNP, however rural workers remain a significant proportion of the working poor in Brazil. The concentration of land ownership among few landowners and large areas of nonproductive rural properties, with few job opportunities has led to migration flows to urban areas. The Movimento dos Sem Terra (Landless People's Movement) is a powerful group of displaced, jobless rural workers that struggle for changes in land tenure polices and legislation that would allow for a more equitable distribution of land, access to credit and technology, and a fairer structure to the retail market 19 .

In addition, informal workers are not eligible to social security benefits and legal labor rights. They are forced to deal with poor work conditions, a lack of safety and health protection and are exposed to poor work environments.

\section{A brief overview of workers' health}

The Brazilian labor market is characterized by increasingly adverse, unregulated and unprotected jobs, and unemployment. Further, there is a knowledge gap about how these conditions affect the health status of workers and healthrelated inequalities.
A study carried out by Gonçalves 20 demonstrated that the self reported health status of unemployed individuals is worse that that reported by the employed. She demonstrated that Brazilian males that are unemployment but not covered by social protection have immediate and delayed effects on their health, even after taking into consideration age, schooling and race. In spite of their worse health indicators, men with informal jobs or those who are unemployed reported that they used health services less, and medical visits in particular. The author also observed that living in a household with an unemployed person or someone with an unregulated job led to a deterioration of the self reported health status of all other residents.

It is important to take into consideration that there is evidence of an epidemiological transition in Brazil, characterized by a continuous decrease in infectious disease related mortality and an increase in non-transmittable, chronic diseases and violent deaths, which also play an important role in workers' health. The nature of work-related diseases and injuries is a mixture of old occupational diseases that are already controlled in developed countries, such as silicosis, pneumoconiosis, lead poisoning, asbestosis, and asbestos-related mesothelioma; and "new" work-related diseases such as musculoskeletal disorders (like carpal tunnel syndrome and others), dermatitis caused by solar radiation and chemical substances, and stress-related disor- 
ders like burn-out, among others. The combination of old-fashioned and new forms of work arrangements implies higher levels of exposure to chemical and physical hazards, repetitive tasks, or long standing use of force, awkward postures, exposure to psychosocial stress and psychosocial factors, causing temporary and long-term disability and suffering 21 .

External causes, injuries and poisoning together represent the fourth highest cause of death (12.6\%), ranking highest among the 5 to 39 age range. Among people aged between 15 and 19 this group of causes accounts for approximately $80 \%$ of all deaths. Homicides rank first among all external causes of death, accounting for nearly $30 \%$. Among them traffic accidents increased rapidly until the mid 1980s then showed a slight decrease up to 1990 . In 1995, a total of 255,000 accidents with victims were registered, corresponding to 321,000 affected people and 25,513 deaths. Most of these deaths are known to be work related although they are often underreported 5 .

Since poor work conditions are shared by both informal and formal workers several empirical studies failed to demonstrate less favorable occupational health indicators among informal workers as compared to formally hired workers for non-fatal occupational accidents 22 .

During the last 20 years there has been a steady decline in the numbers of fatal work-related accidents 21 . This trend has been interpreted as being the result of an increase in participation in the services sector, of the migration of formal workers towards the informal economy, and of changes in the reporting system, since there is no evidence that effective actions for prevention have taken place across Brazil 23,24.

Between 2000 and 2002, the National Social Insurance Institute (INSS) recognized 58,978 cases of work-related diseases, but a large number of cases remains unknown. National statistics and epidemiological data are still relatively scant and of poor quality. The Brazilian Ministry of Social Security releases annual reports but they are limited to formal workers, who make up only $23 \%$ of eligible workers, while even public officers and the military are excluded. According to official data, in 2005 approximately 2,700 workers died and 491,000 were unable to work and received compensation benefits because of occupational injuries.

New cases of silicosis are appearing in spite of national efforts to eradicate this disease 25 . Mesothelioma and other asbestos-related respiratory diseases are appearing in heath statistics 26 . Work-related asthma is becoming a highly frequent respiratory disease, in spite of scarce recognition of them among physicians 27 . Work- related musculoskeletal disorders (WMSDS) are the leading cause of work-related diseases 28 . Mental disorders due to exposure to mercury, lead, manganese or organic solvents are common. Non-organic mental disorders are recognized as a leading occupational health problem resulting from organizational structures and interpersonal relationships at work 29 , shift work 30 , and traumatic events. Noise-induced hearing loss (NIHL) is a highly prevalent work-related disabling disease 31. Among rural workers, the incidence of work-related injuries seems to be higher than the estimates reported in urban areas. Fehlberg 32 estimated an incidence of $11 \%$ of occupational accidents among farm workers, in a southern state of the country. The increasing growth of pesticide consumption in Brazil led the country to be the world's fourth ranked user. Faria et al. 33 estimated a 2.2/100,000 incidence of acute poisonings among farm workers during the period 2001-2002.

It is worth noting that, regardless of the prominence of the informal economy in Brazil, a few studies have addressed the impact of these conditions on health or workers' health. Some studies are descriptive and have no reference group which limits conclusions, and epidemiologic surveys have been developed only in specific areas, meaning that they are not sufficient to draw a real picture of such a diverse country. Official statistics are limited because of large levels of underreporting of fatal or non-fatal cases of occupational diseases and accidents and the poor quality of occupational or industrial trade registrations, particularly for informal workers. Further studies are needed to advance the Brazilian List of Work-Related Diseases regarding work-related disorders currently classified as "unemployment and special adverse working conditions and labor relationships", in the 10th Revision of the International Classification of Diseases (Z56). It is also necessary to stimulate the inclusion of employment relations in the census data or in nationwide systematic studies such as PNAD, and encourage research on the effects of employment relations and work conditions on health, and specifically on health inequities, beyond the limits of occupational-related diseases and accidents.

\section{Political responses}

Brazilian Constitutional Rights include the right to work, the fairness of work relations, the equitable distribution of products and profits, good health and safety conditions in the workplace, reduced environmental impact, actions concern- 
ing health promotion, disease prevention and rehabilitation and social security.

Labor legislation guarantees protection against arbitrary or unjustified dismissal, unemployment compensation and a minimum wage. Other elements guaranteed under law include a bonus of one month's salary at the end of each year; a working day of no more than eight hours or 44 hours per week, along with a weekly day of rest, preferably on Sundays, four weeks annual paid leave, paid retirement, and paid maternity and sick leave. Workers also have the right to work in healthy and safe environments, and for those obliged to be in unhealthy or dangerous roles an additional bonus is granted. Unemployment benefits cover former workers who have held a formal job within the previous six months, and whose dismissal was not due to crime or misconduct (justa causa). But, the great problem is that workers covered by these regulations represent less than $40 \%$ of the EAP.

The Brazilian Ministry of Labor and Employment has been acting directly over slave-like situations through its Special Mobile Inspection Group. In order to carry out more permanent actions, the Brazilian government created a National Plan for the Eradication of Slave Work 34, for which responsibility is shared among the executive, legislative and judiciary powers, as well as the Public Ministry, and civil society and international groups.

To fight against child labor, the federal government launched the Child Labor Eradication Program (PETI) in 1996. The program assisted over 800,000 children. It is estimated that the child labor rate in Brazil decreased from $13.7 \%$ in 1995 to $8.2 \%$ in 200235 .

The Brazilian Ministry of Health has been implementing a set of actions with the purpose of applying the Health Act of 1990 which makes the Brazilian Unified National Health System (SUS), responsible for workers' health surveillance, health and medical care, and health promotion. The National Workers' Health Care Network (RENAST) was launched in 2003 and nowadays is the key strategy for health policy among workers. RENAST is a hierarchical health care network comprising the administrative arms of federal (Ministry of Health), state (State Secretariats) and municipal (Municipal Secretariats) governments. It involves partnerships between various ministries and civil society for planning, setting priorities, and making budgetary decisions 36 .

In 2004, the Brazil National Health Council launched the Third National Workers' Health Conference (CNST3) developed jointly by the ministries of Health, Labor and Social Security aimed to develop an integrated federal policy for workers' health that involved government institutions, labor unions, health professionals, social movements, academic representatives and other relevant stakeholders. The CNST3 final product was an agenda defining priorities and guidelines over three main priorities: workers' health; sustainable development; and social participation in planning and management of occupational health care.

Changes in the labor market structure have been affecting the Brazilian social security system. In 2004, the proportion of tax-payers in the social security system was $40.6 \%$ of the EAP. This problem has been addressed by the Brazilian Ministry of Social Security through several actions, including the creation of alternative forms that include workers from the informal economy based on a subsidized quota for self-employed workers.

The creation of the Brazilian Ministry of Social Development in January 2004 led to a significant increase in the budget for social protection. Since 2000, programs for money transfers, food and nutritional safety, social assistance and inclusion in the labor market have been implemented, with a substantial expansion of coverage of the social assistance network. In May 2006, the Family Compensation Program included 9.2 million families enrolled, accounting for $83.2 \%$ of the protected poor families in Brazil 37.

Some of the problems regarding the Social Security model are: administrative inefficiency; financial problems and large debts; a concentration of protected workers amongst the middle classes and the exclusion of low income and poor social groups; and the impacts of regressive distribution. Although unemployment rates have increased, the eligibility for unemploymentcompensation has not been expanded 38 .

\section{Final remarks}

Equity concerns about workers' health are highly valued and deserve a high priority in any social policy agenda. However, it seems that most "traditional" approaches to occupational and safety promotion and protection have not been enough, so far, to reduce the increasing gaps in this field. So, innovative and "non-conventional" approaches must be explored and taken into consideration. The complexity of the problem of workers' health requires the participation of a variety of actors at both national and international levels, particularly in the context of globalization, with a special focus required for reaching unemployed or underemployed workers that are not 
protected by private or public Health Insurance and Workers' Compensation schemes.

Workers play a fundamental role in the transformation of this reality. It is necessary to cre- ate mechanisms to facilitate participation and to improve information and democratic forums to guarantee social justice, equity and peace.

\section{Resumo}

Este trabalho descreve aspectos das condições de trabalho e emprego e suas relações com a saúde, no contexto brasileiro, enfatizando as desigualdades sociais relacionadas com a inserção no mercado de trabalho, tendo sido desenvolvido como contribuição ao documento da rede "Employment Conditions and Health Inequalities Knowledge Network (EMCONET) - WHO Commission on Social Determinants of Health". A pesquisa bibliográfica foi realizada no SciELO, LILACS, Google, Google Scholar, MEDLINE e no banco de teses da CAPES. No Brasil, o número de trabalhadores inseridos no setor informal supera o daqueles no setor formal. As informações sobre adoecimento e morte relacionados ao trabalho não estão disponíveis para o conjunto da população economicamente ativa. As condições de trabalho e saúde são ruins em ambos os grupos e, apesar do complexo arcabouço legal referente à proteção dos trabalhadores e de avanços setoriais, as políticas públicas permanecem fragmentadas, apresentam baixa cobertura e pouca eficácia. O crescente envolvimento do movimento social e de sindicatos de trabalhadores na elaboração e gestão de políticas e programas de saúde sinaliza um processo promissor em curso no país.

Saúde do Trabalhador; Condições de Trabalho; Mercado de Trabalho

\section{Contributors}

All the authors participated in the article's conceptualization. E. C. Dias and V. S. Santana wrote the first draft, which was reviewed by R. P. Oliveira and E. C. Dias and received original contributions from the other authors (J. H. Machado, C. Minayo-Gomez, M. A. G. Perez, and M. G. L. Hoefel). All seven authors reviewed and approved the final format. 


\section{References}

1. Siegrist J. Place, social exchange and health: proposed sociological framework. Soc Sci Med 2000; 51:1283-93.

2. Lynch J, Kaplan G. Socioeconomic position. In: Berkman LF, Kawachi I, editors. Social epidemiology. New York: Oxford University Press; 2000. p. 13-35.

3. Carvalho JAM. Crescimento populacional e estrutura demográfica no Brasil. Belo Horizonte: Centro de Desenvolvimento e Planejamento Regional, Universidade Federal de Minas Gerais; 2004. (Trabalho para Discussão, 227).

4. Instituto Brasileiro de Geografia e Estatística. Síntese de indicadores sociais 2002. Rio de Janeiro: Instituto Brasileiro de Geografia e Estatística; 2003. (Estudos e Pesquisas, 11).

5. Wünsch Filho V. Demographic and epidemiological transitions of workers' health. OSH \& Development 2006; 8:33-9.

6. Departamento Intersindical de Estatística e Estudos Sócio-Econômicos. O mercado de trabalho brasileiro no início de 2004. São Paulo: Departamento Intersindical de Estatística e Estudos Sócio-Econômicos; 2004.

7. Neri M. 40 milhões de trabalhadores sem previdência social. Conjuntura Econômica 2001; 66-8.

8. Dias EC, Mendes R, Schwartz B. Occupational health in Brazil. Occup Med 2002; 17:523-37.

9. Mendes R. Current needs in developing countries: Brazil - brief introduction to the country and the OSH panorama. http://www.renemendes.com.br/ entrada/noticia/view.asp?id_noticia $=76$ (accessed on 20/May/2007).

10. Instituto Brasileiro de Geografia e Estatística. Pesquisa Nacional por Amostra de Domicílios. http://www.ibge.gov.br/english (accessed on 14/ Jul/2007).

11. Instituto de Pesquisa Econômica Aplicada. Radar social. Brasília: Instituto de Pesquisa Econômica Aplicada; 2006.

12. Pochman M. O trabalho sob fogo cruzado. 2a Ed. São Paulo: Editora Contexto; 2000.

13. Fagundes TLQ. Trabajo, estrategias de supervivencia y la salud de los niños y las ninas en los países en las regiones de las Américas. Washington DC: Organización Panamericana de la Salud; 1994.

14. Barros RP, Mendonça R. Os determinantes da desigualdade no Brasil. In: Instituto de Pesquisa Econômica Aplicada, organizador. A economia brasileira em perspectiva. Rio de Janeiro: Instituto de Pesquisa Econômica Aplicada; 1996. p. 412-73.

15. Wanjman S, Perpétuo IHO. A redução do emprego formal e a participação feminina no mercado brasileiro. Nova Economia 1997; 7:123-47.

16. Ramos L. O desempenho recente do mercado de trabalho brasileiro: tendências, fatos estilizados e padrões espaciais. Brasília: Instituto de Pesquisa Econômica Aplicada; 2007. (Texto para Discussão, 1.255).

17. Ministério da Saúde. Trabalho infantil: diretrizes para a atenção integral a saúde de crianças e adolescentes economicamente ativos. Brasília: Ministério da Saúde; 2006.
18. Ministério do Trabalho/Comissão Especial do Conselho de Defesa dos Direitos da Pessoa Humana, Secretaria Especial dos Direitos Humanos/Organização Internacional do Trabalho. Plano nacional para a erradicação do trabalho escravo. Brasília: Organização Internacional do Trabalho; 2003.

19. Carneiro FF. A saúde no campo - das políticas públicas à experiência do MST e de famílias "bóias frias" em Unaí, Minas Gerais [Tese de Doutorado]. Belo Horizonte: Programa de Pós-Graduação de Saúde Animal, Universidade Federal de Minas Gerais; 2007.

20. Gonçalves LG. Desemprego, trabalho sem proteção social e saúde: uma análise do indivíduo e do contexto [Tese de Doutorado]. Belo Horizonte: Programa de Pós-Graduação em Saúde Pública, Universidade Federal de Minas Gerais; 2008.

21. Gómez C, Lacaz FAC. Saúde do trabalhador: novas-velhas questões. Ciênc Saúde Coletiva 2005; 10:797-807.

22. Santana V, Nobre L, Waldvogel BC. Acidentes de trabalho no Brasil entre 1994 e 2004: uma revisão. Ciênc Saúde Coletiva 2005; 10:841-56.

23. Wünsch Filho V. Reestruturação produtiva e acidentes de trabalho no Brasil: estrutura e tendências. Cad Saúde Pública 1999; 15:41-51.

24. Santana VS, Loomis D. Informal jobs and nonfatal occupational injuries. Ann Occup Hyg 2004; 48:147-57.

25. Castro HA, Novello CH, Santos MBM, D'Acri V, Souza KR, Menezes MAC. A vigilância ambiental em saúde de populações expostas ao amianto no Brasil. Cad Saúde Colet (Rio J) 2005; 13:195-208.

26. Mendes R. Asbesto (amianto) e doença: revisão do conhecimento científico e fundamentação para uma urgente mudança da atual política brasileira sobre a questão. Cad Saúde Pública 2001; 17:7-29.

27. Faria NMX, Facchini LA, Fassa AG, Tomasi E. Trabalho rural, exposição a poeiras e sintomas respiratórios entre agricultores. Rev Saúde Pública 2006; 40:827-36.

28. Murofuse NT, Marziale MHP. Doenças do sistema osteomuscular em trabalhadores de enfermagem. Rev Latinoam Enfermagem 2005; 13:364-73.

29. Brant LC, Dias EC. Trabalho e sofrimento em gestores de uma empresa em reestruturação. Cad Saúde Pública 2004; 20:942-9.

30. Guimarães LA, Teixeira LN. Transtornos mentais e trabalho em turnos alternados em operários de mineração de ferro em Itabira (MG). J Bras Psiquiatr 2003; 52:283-9.

31. Sakae TM, Sakae O, Adams R, Kuntze AC. Perfil epidemiológico e audiológico dos trabalhadores atendidos pelo Serviço Social da Indústria de Blumenau - Santa Catarina. ACM Arq Catarin Med 2006; 35:28-34.

32. Fehlberg MF, Santos I, Tomasi E Prevalência e fatores associados a acidentes de trabalho em zona rural. Rev Saúde Pública 2001; 35:269-75.

33. Faria NMX, Fassa AC, Fachinni LA. Intoxicação por agrotóxicos no Brasil: os sistemas oficiais de informação e desafios para realização de estudos epidemiológicos. Ciênc Saúde Coletiva 2007; 12:25-38. 
34. Departamento de Fiscalização do Trabalho, Secretaria de Inspeção do Trabalho, Ministério do Trabalho. Resultados da fiscalização do trabalho: janeiro a dezembro de 2006. http://www.mte. gov.br/fisca_trab/est_fiscatrab_janeiro_setem bro2006.pdf (accessed on 20/May/2007).

35. Carvalho IMM. Algumas lições do programa de erradicação do trabalho infantil. São Paulo Perspect 2004; 18:50-61.

36. Dias EC, Hoefel MG. O desafio de implementar as ações de saúde do trabalhador no SUS: a estratégia da RENAST. Ciênc Saúde Coletiva 2005; 10:817-28.
37. Vaitsman J, Rodrigues RWS, Paes-Sousa R. O sistema de avaliação e monitoramento das políticas e programas sociais: a experiência do Ministério de Desenvolvimento Social e Combate à Fome do Brasil. Brasília: Organização das Nações Unidas Para a Educação, a Ciência e a Cultura; 2006.

38. Dias EC. O desafio da construção da equidade em saúde no trabalho: a contribuição das políticas públicas de saúde, trabalho, previdência social e ambiente. In: Mendes R, Facci R, Handar Z, organizadores. $O$ desafio da equidade em saúde e segurança no trabalho: temas de saúde ocupacional nos países da América Latina. São Paulo: Editora VK; 2004. p. 29-55.

Submitted on 24/Apr/2008 Approved on 30/May/2008 